\title{
Májsebészet a Semmelweis Egyetem I. sz. Sebészeti Klinikáján
}

\author{
HAHN OSZKÁR, KUPCSULIK PÉTER, PEKLI DAMJÁN, FÜLÖP ANDRÁS, \\ BÁRDOS DÁVID, KOKAS BÁLINT, SZIJÁRTÓ ATTILA
}

Semmelweis Egyetem, I. sz. Sebészeti Klinika, Budapest

\section{Bevezetés}

A magyar orvosképzés 1769-ben, a nagyszombati egyetem megnyitásával kezdődött. Az önálló orvosi fakultás hivatalosan 1770-ben alakult meg. A sebészetet és a szülészetet együtt oktatták. Nem voltak önálló klinikák. Budán $1777-$ ben kezdődött a sebészet oktatása, a gyakorlatok a „Szegények házában" (mai János kórház területén) történtek. 1791-től a hatvani utcában a 36 egyetemi betegágyból már 9 sebészeti volt. 1858-tól a Múzeum körúti „Kunewalder” házban 27, majd 1869-től már 36 sebészeti ágy van. 1875ben nyílik meg az Üllői út-Mária utca sarkán az új sebészeti Klinika 72 ággyal. Ez ugrásszerü fejlődést jelent, különös tekintettel arra, hogy a szülészet levált a sebészetről.

A szakma fejlődését és jelentőségét az bizonyítja igazán, hogy alig néhány évtizeddel később, 1909-ben az Üllői út 78. szám alatt megnyitják a kor - nemzetközi összehasonlításban is - legmodernebb sebészeti klinikáját. Az idén 111 éves épület 120 ággyal indult. ${ }^{1}$

A májsebészet áttekintését megelőzően nem hagyható említést nélkül az a nem feltétlenül közismert tény, hogy a Klinika első tanszékvezetője, Dollinger Gyula hozta létre a világ első rákregiszterét. A modern, új épület falait a kezdetektől korszerű szellemiség lengte át. A máj sebészete felhúzta a maga korában divatos gyerekcipőjét, és járni próbált.

Ahhoz, hogy megérthessük, miért volt a XX. elején szinte „lehetetlen küldetés” a májon végzett mütét, szükséges áttekinteni néhány alapfeltételt.

Májmütét rizikófaktorai:
a) kórismézés,
b) kombinált intratrachealis narkózis,
c) vérzés-transzfúzió,
d) sebészi eszközök,
e) maradékmáj, regeneráció.

a) A kórismézésről nem is érdemes szót ejteni. A klinikai adatokra és a fizikális vizsgálatokra kellett hagyatkozniuk. UH, CT, MRI még a vágyálmokban sem létezett, röntgen viszont már igen. Az első magyarországi röntgenfelvétel 1896-ban Eötvös Loránd kezéről a Természettudományi Közlöny januári számában jelent meg. Különösen érdekes, hogy az első klinikai alkalmazás éppen Dollinger nevéhez füződik: ugyanez év februárban röntgenfelvétel segítségé- vel revolvergolyót talált meg egy férfi kezében, és azt így már „egy kis preparálással könnyen el lehetett távolítani”. Nem tudjuk biztosan, használtak-e röntgenkészüléket a máj vizsgálatára, de az biztos, hogy a Klinika élen járt a röntgensugarak alkalmazásában. Szomorú bizonyítéka ennek, hogy az itt dolgozó első magyar klinikai radiológus, sebész egyetemi tanár dr. Holzwarth Jenő (1874-1922) neve is szerepel a Hamburgban 1936-ban felállított emlékmüvön, amely a röntgensugárzás következtében elhunyt orvosok, kutatók mementója.

b) Döntően helyi érzéstelenitésben operáltak. Éternarkózis volt, intubáció, relaxáns, antibiotikum nem. Az aneszteziológia szakma még nem létezett.

c) Transzfúzió. A vércsoportok felfedezése Landsteiner nevéhez füződik (1901-1902). Csoportazonos vér adására a Klinika korai éveiben biztosan sor került. 1918-21 között a Klinika munkatársa volt Kubányi Endre, aki amerikai tanulmányútját követően 1935-ben (a Madarász utcai Gyermekkórházban) létrehozta az első hazai véradóállomást.

d) A sebészi eszközök alapszintűek voltak, májreszekcióra alig alkalmasak. Hogy milyen gondot jelentett „,vágást ejteni a májon”, példázza az alábbi idézet (Lumniczer József, A Magyar Sebésztársaság Munkálatai 3. nagygyülés, 1910. május 27-28.): „A máj ballebenyéből, mely jelentékenyen megnagyobbodott $\mathrm{kb}$. felerészét távolítottam el, a mi vastagsága helyenkint $4^{\prime} 8 \mathrm{~cm}$, sőt a legmagasabb részletben $10 \mathrm{~cm}$ vastag volt. Mütétnél kevés vérveszteség. A midőn azonban a máj resecált felületeit összehozni akartuk a májseb felső zugában berepedt s óriási vérzés keletkezett. Miután tamponokkal, ujjlenyomással, csiptetővel megszüntetni a profus vérzést nem sikerült, a máj egész vastagságát átöltő varratokkal a májból ismét két ujjnyi részletet vettünk le. Erre a vérzés megszünt.”

e) A kezdeteknél ezek a fogalmak ismeretlenek voltak.

\section{A kezdetek}

Korai májmütétek a Sebészeti Klinikán: 1897-1907 között 42 echynoccus cysta fenestratio (exit = 8) 1907-1908 Abs- 
cessus: 1, Echynococcus: 1, Syphilises gumma: 1, tumor: 1 . A Klinikán az 1960-as évekig csak kevés májmütét történt. Innentől kezdődően Szécsény Andor munkásságának köszönhetően egyre nagyobb számban végeztünk különféle reszekciókat. A fejlődést - nem alábecsülve a sebészi képességeket - mindenekelőtt az aneszteziológia átalakulása tette lehetővé. Hedri Endre amerikai útja után 1948-ban kezdeményezte az önálló aneszteziológiai szakma megalakulását. Intratracheális intubációt az 50-es évek végétöl alkalmaztak. 1963-tól a Rubányi Pál vezette Klinikán aneszteziológusi csoport müködött Szenohradszky Vilmos, majd Megyaszai Sándor vezetésével. A májreszekciók akkori javallatait elsősorban kolorektális májáttétek, esetenként benignus daganatok (FNH, haemangioma, adenoma) képezték. Sor került kiterjesztett reszekciókra, ideértve lobektomiát, trisegmentektomiát is. A Klinikán a májreszekciók alatti vérzés csökkentésére portális leszorítást alkalmaztak. Ennek standard eljárása a 70-es évek elejére alakult ki: $2 \times$ 30 perc, közte $2-3$ perces szünet „flush” perfúzióval. Évente 20-30 jelentősebb májreszekció történt.

A hatvanas évek elejétől - elsősorban Szécsény Andor munkásságának köszönhetően - a Klinika úttörö szerepet vállalt a portális hipertenzió kezelésében. Bár a májsebészethez csak korlátozottan köthető a tevékenység, mégis fontos megemlíteni a nyelőcsővisszér-vérző betegeken elvégzett portális nyomást csökkentő, már akkor alig elfogadható mértékủ mortalitással (50\%) bíró porto-szisztemas shuntműtéteket, illetve a halálozást jelentősen csökkentő endoszkópos varixkezelést. ${ }^{2,3} \mathrm{Az}$ akut vérzők halálozása $10 \%$ alá esett, a választott kezeléseké $0,2 \%$ körül volt. Sebészek, belgyógyászok, fül-orr-gégészek, aneszteziológusok olyan csapata alakult így ki, amely bármikor hajlandó volt az életmentő kezelések elvégzésére. Ez a csapatszemlélet a klinikán a kezdetektől a mai napig tetten érhető.

$\mathrm{Az}$ ascites peritoneo-venosus shuntbeültetéssel történő kezelése 1983-ban indult, a legnagyobb hazai beteganyag (265 beteg) gyült össze az évek során. ${ }^{4}$

A Klinika kísérleti mütőjében 1965 óta folytak olyan állatkísérletek, amelynek célja a máj konzerválása, illetve bizonyosan a beültetés gyakorlása volt. ${ }^{5-7}$

A Klinika több munkatársa tett látogatást külföldi transzplantációs munkacsoportoknál (Roy Calne, Cardiff; Rudolf Pichlmayr, Hannover; Thomas E. Starzl, Pittsburgh). Az első magyarországi májátültetés 1983. február 1-én történt. ${ }^{8}$ A 12 éves recipiens krónikus aktív HBsAg-pozitív hepatitisben szenvedett, ismétlődő hepatargiás kóma, ascites miatt feküdt a Bethesda kórházban. A rohamos progresszió a transzplantáció sürgős javallatát képezte. A donor egy balesetet szenvedett 38 éves férfi volt. A májátültetés 1983. február 1-én 21.50-kor indult, időtartama 7 óra 15 perc volt. A teamet Szécsény Andor vezette. A gyermek 24 órás gépi lélegeztetés után extubálható volt. Az epeelválasztás a Kehr-csövön keresztül azonnal megindult. Az immunoszupressziót Solu-Medrollal és Imurannal kezdtük. Az első májtranszplantáció különlegessége volt, hogy Magyarországon elöször került sor Cyclosporin A alkalmazására. A gyógyszer adását a mütét utáni 3. na- pon kezdtük el. Ekkor szubakut rejekció jelei voltak észlelhetők, melyek fokozatosan rendeződtek. Jóllehet a máj müködése stabil volt, sebészi szövődmény sem lépett fel, de disszeminált Cytomeglovirus-fertőzés alakult ki, és a tüdőszövődmények a posztoperatív 64. napon a beteg halálát okozták. Acyclovir és származékai ebben az időben ismeretlenek voltak. Még két további májtranszplantációra került sor, az egyik esetben bal oldali májszegment-beültetés történt. Ezt követöen a májtranszplantáció az újonnan alakuló Transzplantációs és Sebészeti Klinikára került.

\section{A modern kor}

A májsebészet fejlődésének második szakasza a 2000-es évek elejére tehető. Ekkor léptük át a „maradék májtömeg” értelmezési „Rubicon”-ját. Olyan májreszekciók váltak tervezhetővé, ahol a kiindulási helyzetben a reszekciót követő maradék máj (FLR) a szükségesnél (30-40\%) kisebb volt. A tumoros oldali portatörzs elzárása (PVL) ellenoldali májregenerációt eredményez. A maradék májtömeg növekedésével így válik lehetôvé a kiterjesztett reszekció. A máj irányított regenerációjának vizsgálatának és klinikai alkalmazásának elindítása Kupcsulik Péter nevéhez köthető. Az első ilyen mütétre 2001 januárjában került sor - hazánkban először. A „portaligatúra” mútétek száma fokozatosan növekedett.

A következő lépést a 2007-ben megnyitott angiográfás laborban lehetővé vált perkután ultrahangvezérelt punkciót követő transzhepatikus vena portae embolizáció (PVE) jelentette. Az eljárás előnye a viszonylagosan alacsony invazivitás, a ligatura mütét elkerülése. 245 PVL-PVE beavatkozás történt. Manapság már a mindkét májlebenyt érintő tumorok esetén is lehetséges kuratív mütéti eljárás, ha legalább 1 segment tumormentessé tehető, vérellátása, epeelfolyása és a beteg májmüködéséhez szüksége funkcionális térfogata biztosítható. A májreszekciót ilyenkor gyakran két lépcsőben végezzük, mely során az egyik oldali tumor(ok) eltávolítása, majd a megfelelő méret elérését követően a másik oldal reszekciója vagy a tumor(ok) excisiója következik. $^{9}$

A májtérfogat növekedése nem minden esetben az elvárt mértékben jön létre, még akkor sem, ha a portális okklúzió technikailag korrekt. Ennek oka a májlebenyek közötti intraparenchimális portális (és artériás) kollaterális kapcsolat. Ha az okklúzióval egyidejűleg „in situ splitet" alkalmazunk, a regeneráció mértéke és sebessége növekszik. (ALPPS: Associated Liver Partition and Portal vein ligation for Staged hepatectomy). Az első ilyen mütét 2012-ben történt a klinikán és először hazánkban. ${ }^{10}$ A rendkívül magas reszekciós arány ellenére a szövődmények lehetősége miatt az eljárás csak szoros feltételek mellett történő betegszelekció után végezhető. Az eljárás kidolgozásában, a szövődmény arányának csökkentésében, a mütéti technika módosításában klinikánk világviszonylatban is vezető szerepet játszik ${ }^{11-13}$ csakúgy, mint az egyéb vena portae okklúziós technikák klinikai alkal- 
mazásában, kutatásában és állatkísérletes sebészi modellezésében ${ }^{14-16}$.

Mindmáig rutineljárásként alkalmazzuk a maradékmáj-volumen manipulációs technikákat, bár gyakoriságuk némileg csökken. Ennek oka az, hogy a májreszekciók leggyakoribb javallatának számító kolorektális májáttétek esetén a májreszekció kiterjesztésének lehető elkerülésére az ún. ,parenhimaspóroló” technikák váltak klinikai gyakorlattá, így az intraoperatív, ultrahangvezérelt, ún. eOSH (enhanced One Stage Hepatectomy) mütéti eljárást alkalmazzuk gyakrabban többgócú kolorektális májáttétek esetén. ${ }^{9}$

A sebészi eszközpark fejlődése, ideértve az intraoperativ, illetve laparoszkópos ultrahangvizsgálatot és a speciális CT-, illetve MRI-vizsgálati lehetőséget, új távlatokat nyitott.

A 21. század elejétől jelentős változások következtek be a májsebészetben. A korábban jóindulatú daganatok miatt nagyszámban végzett májreszekciók aránya drasztikusan csökkent világszerte, így klinikánkon is. A benignómák (májciszta, adenoma, FNH, hemangioma, echinococcus cysta) mütéti javallati köre szükült, manapság a panaszt nem okozó, akár nagyméretủ jóindulatú májtumorok többségét nem operáljuk. A máj adenoma kivételével sem malignizálódási potenciáljuk nincs, és szövődményük (ruptura, bevérzés, epeút vagy érkompresszió) is csak rendkívül ritkán fordul elő. A sokat javuló képalkotó diagnosztika és a szükség esetén elvégzett perkután szövettani mintavétel miatt a diagnosztikus tévedés aránya kicsi, a pontos preoperativ tervezés és nem elhanyagolható mértékben a különböző disszekciós eszközök eredményeként a korábbi „standard" portális leszorítás és annak módosított változatai ${ }^{17,18}$ csak elvétve fordulnak elő. A kezdetekkor kivételesen fontos transzfúzió adta biztonság - bár ma is szükséges inkább csak háttér: a reszekciók többsége vérátömlesztés nélkül történik meg.

A korábban Magyarországon is gyakori echinococcus cysta előfordulása jelentősen csökkent, gyógyszeres kezelés mellett ma már csak a kompressziót és/vagy epeút és/ vagy ér ,inváziót” mutató cisztákat, illetve az antimikrobiális kezelésre nem reagálókat operáljuk. A cisztás elváltozások kezelésében (simplex, policisztás máj, echinococcus) elötérbe kerültek a percutan UH- vagy CT-vezérelt módszerek, melyekben klinikánk szintén úttörő szerepet játszott. ${ }^{19}$

A 2000-es évektől a májreszekciók száma klinikánkon elérte az évi 100-130 mütétet. A világviszonylatban is nagyszámú mütétet világviszonylatban is kiemelkedően alacsony mortalitással végezzük. 2018-ban a kórházi halálozás májreszekciók után $0,87 \%$ volt az I. sz. Sebészeti Klinikán.

A kiemelkedő eredmény mögött sok tényező sorolható fel, de a legfontosabb a nagy tapasztalattal bíró csapat munkája. Hangsúlyosnak érezzük, hogy nem „one man show”ról van szó, hanem egy olyan jól bejáratott tevékenységről, amelyben a májmütétek rutinbeavatkozásnak számítanak, de az olyan, világviszonylatban sem gyakori, bonyolult, kétlépcsős, „,in situ split”-tel kombinált májreszekció észlelése, pre- és posztoperatív kezelése sem, mint a „mono- segment ALPPS”. Ma már egyértelmü, hogy azokban az intézményekben alacsony a szövődmények aránya, ahol a briliánsan megoperált betegek szövődményeit időben észlelni és azt ellátni képes csapat áll rendelkezésre. A kiváló mortalitási mutatóink eléréséhez természetesen szükséges a magas esetszám, az évtizedes (évszázados?) tapasztalat a preoperatív diagnosztikában, a mütéti tervezésben, a májreszekciók kidolgozott, rutinszerü, lehető legkisebb megterhelést jelentő (pl. laparoszkópia) technikával ${ }^{20,21}$ történő elvégzésében, a szükséges speciális eszközök megléte (elektrodisszekciós és laparoszkópos eszközök, intraoperatív ultrahang stb.), a posztoperatív szövődmények korai észlelése és lehetőség szerint minimál invazív technikákkal (percutan UH-vezérelt intervenciók, epeúti intervenciókERCP/PTD) történő ellátása.

A máj primer és áttéti daganatainak mütéti ellátása mellett kifejezett kihívást jelentenek a hilaris epeúti daganatok ellátása is, melyböl évente közel 25-40 mütétet végzünk. Klatskin-tumorok ellátása kapcsán kiemelendő az évtizedes tapasztalatokra alapuló terápiás algoritmus felállítása. Nagy elöny a Klinikánkon napi gyakorlatban alkalmazott, sebészek kezében lévő epeúti intervenciók elérhetősége is. A pre- és posztoperatív kezelési terv felállításának, a szövődmények időben való felismerésének, kezelési sémáinak bevezetése eredményezte azt, hogy az I. sz. Sebészeti Klinika epeúti daganatos betegeinek túlélése, szövődményaránya a nemzetközi átlagban is kiemelkedő.

Utoljára hagytuk, de annál hangsúlyosabbnak érezzük az aneszteziológiai és intenzív terápiás munkatársaink felkészültségét. A korábban említett 60 -as évek höskorához képest ma már a kevés szövődménnyel és vérzéssel, rutinszerủen végzett májreszekciók aneszteziológiai szempontból klinikánkon általában „unalmasak”, azonban ha ritkán különleges, nem várt helyzet adódik, akkor az altatóorvosnak a beteg sorsát döntően befolyásoló szerepe van. A sebész és az aneszteziológus együttműködése a műtét előtti tervezéstől, a mütét transszekciós fázisában összehangolt balanszírozott normál és alacsony CVP változtatásán át a posztoperatív időszakban szükséges megfelelő formájú fájdalomcsillapítás mellett fenntartott kellő májperfúzió eléréséig elengedhetetlenül szorosnak és sokrétünek kell lennie, mely klinikánk saját anesztéziájával sok évtizedes hagyományokon alapul.

Az I. sz. Sebészeti Klinikán ma már minden „profil” ('́gy a májprofil is) csapatban dolgozik, heti 1 alkalommal „teammegbeszélés” keretében beszéljük meg a szakambulanciákon látott betegeket, konzultálva a májmütéteket nagy számban diagnosztizáló és kezelő radiológussal, onkológussal, intervenciós szakemberrel, illetve aneszteziológussal. 2020 szeptemberétől klinikánk az országban egyedülálló sebészi és gasztroenterológiai centrummá alakul, így hepatológus-belgyógyász kollégáink is csapatunk tagjai lesznek, tovább erősítve az ország legnagyobb májsebészeti centrumát.

Klinikánk elkötelezett a májsebészet hazai fejlödésének elősegítésében is, így májsebészeti munkacsoportunk nevéhez füződik a Magyarországon 2019-ben elöször 
megtartott „Colorectalis májmetastasisok komplex kezelése" - Konszenzus konferencia, ${ }^{9}$ és az idén megtartandó „HCC komplex kezelése” - Konszenzus konferencia megszervezése is.

\section{Irodalomjegyzék}

${ }^{1}$ Kupcsulik $P$ (szerk.): Az Üllői úti Sebészeti Klinika, 1909-2009: Jubileumi kiadvány. Budapest: Semmelweis Kiadó, 2009.

${ }^{2}$ Kupcsulik P, Darvas K, Máthé Z, Bodnár A: Esophagoscopic sclerosing therapy for bleeding esophageal varices. Endoscopy 1980; 12: 231.

${ }^{3}$ Kupcsulik P, Bodnár A, Darvas K, Kokas P, Szécsény A: A portalis hypertensio kezelésére alkalmazott mesentericocavalis H-shunttel elért első eredmények. Orv Hetil 1984; 125: 79-81.

${ }^{4}$ Kupcsulik P, Harsányi L, Kokas P: LeVeen shunt beültetésével szerzett tapasztalataink. Orv Hetil 1985; 126(33): 2027-2031.

${ }^{5}$ Kupcsulik P, Stekker K, Németh M: Effect of ischemia on the enzyme activity of the hepatic tissue. Research in Experimental Medicine 1977; 170(3): 259-270.

${ }^{6}$ Kupcsulik P, Faller J, Karácsonyi S: Histochemische Untersuchung der nichtspezifischen sauren und alkalischen Phosphatase, Adenosin-tiphosphatase und Laktat-dehydrogenase der in vitro perfundierten Hundeleber. Gegenbaurs Morphologisches Jahrbuch 1974; 120(5): 638-657

${ }^{7}$ Kupcsulik P, Stekker K, Németh M: Effect of ischemia on the enzyme activity of the hepatic tissue. Research in Experimental Medicine 1977; 170(3): 259-270.

${ }^{8}$ Szécsény A, Darvas K, Faller J, Kupcsulik P: Az első hazai májátültetés klinikai esetismertetése. Korányi S. Társ. Tud. Közleményei 1986; 229-234.

${ }^{9}$ Magyar Hepato-Pancreatico-Biliaris (HPB) Kutatócsoport, Semmelweis Egyetem, Általános Orvostudományi Kar, Üllői út 78., 1082 Budapest, Hungary, András C, Bartek P, Battyáni I, Bezsilla J, Bodoky G, Bogner B, Bursics A, Csőszi T, Damjanovich L, Dank M, Dankovics Z, Deák PÁ, Dede K, Doros A, Dudás I, Györke T, Hahn O, Hartmann E, Hitre E, Horváth Z, Imre M, Kalmár Nagy K, Káposztás Z, Kóbori L, Kupcsulik P, Landherr L, Lóderer Z, Mangel L, Máthé Z, Mersich T, Mezei K, Mohos E, Oláh A, Pajor P, Palkó A, Pápai Z, Papp A, Patyánik M, Petri A, Révész J, Ruzsa Á, Schlachter K, Sikorszki L, Sipőcz I, Székely E, Szijártó A, Torday L, Tóth LB, Dósa E, Harsányi L, István G, Landherr L, Lázár G, Lövey J, Schaff Z, Szücs Á, Vereczkei A: Colorectalis májmetastasisok komplex kezelése. Konszenzuskonferencia, Budapest, 2019. április 5. Orv Hetil. 2019. Sep; 160(Suppl 2): 2-20.

${ }^{10}$ Hahn O, Dudás I, Pajor P, Györke T, Korom C, Zsirka-Klein A, Kupcsulik P, Harsányi L [ALPPS (Associated Liver Partition and Portal vein ligation for Staged hepatectomy) - faster and greater growth of liver]. Magy Seb. 2013. Feb; 66(1): 21-26.
${ }^{11}$ Hahn O, Bárdos D, Kupcsulik P, Szijártó A, Fülöp A, Kokas B, Pekli D, Zsirka-Klein A, Dudás I, Pajor P, Harsányi L: Speciális májmütét (Associating Liver Partition and Portal vein ligation for Staged hepatectomy, ALPPS) morbiditásának csökkentése átértékelt betegkiválasztási elvek és mütéttechnikai módosítás révén. Orv Hetil 2019. Aug; 160(32): 1260-1269.

${ }^{12}$ Li J, Moustafa M, Linecker M, Lurje G, Capobianco I, Baumgart J, Ratti F, Rauchfuss F, Balci D, Fernandes E, Montalti R, Robles-Campos R, Bjornsson B, Topp SA, Fronek J, Liu C, Wahba R, Bruns C, Brunner SM, Schlitt HJ, Heumann A, Stüben BO, Izbicki JR, Bednarsch J, Gringeri E, Fasolo E, Rolinger J, Kristek J, Hernandez-Alejandro R, Schnitzbauer A, Nuessler N, Schön MR, Voskanyan S, Petrou AS, Hahn O, Soejima Y, Vicente E, Castro-Benitez C, Adam R, Tomassini F, Troisi RI, Kantas A, Oldhafer KJ, Ardiles $V$, de Santibanes E, Malago $M$, Clavien PA, Vivarelli $M$, Settmacher U, Aldrighetti L, Neumann U, Petrowsky H, Cillo U, Lang H, Nadalin S: ALPPS for Locally Advanced Intrahepatic Cholangiocarcinoma: Did Aggressive Surgery Lead to the Oncological Benefit? An International Multi-center Study. Ann Surg Oncol. 2020 May; 27(5): 1372-1384.

${ }^{13}$ Wanis KN, Linecker M, Madenci AL, Müller PC, Nüssler $N$, Brusadin R, Robles-Campos R, Hahn O, Serenari $M$, Jovine E, Lehwald N, Knoefel WT, Reese T, Oldhafer K, de Santibañes $M$, Ardiles $V$, Lurje $G$, Capelli R, Enne $M$, Ratti $F$, Aldrighetti L, Zhurbin AS, Voskanyan $S, M a-$ chado M, Kitano Y, Adam R, Chardarov N, Skipenko O, Ferri $V$, Vicente E, Tomiyama $K$, Hernandez-Alejandro $R$ : Variation in complications and mortality following ALPPS at early-adopting centers. HPB (Oxford). 2020 May 23:S1365-182X(20)30133-7.

${ }^{14}$ Szijártó A, Hargitai B, Fischer S, Darvas K, Kupcsulik P: Two-staged procedure of portal ligation and hepatectomy monitored by ICG clearance. J Invest Surg. 2009; 22(1): 63-68.

${ }^{15}$ Fülöp A, Szijártó A, Harsányi L et al.: Demonstration of metabolic and cellular effects of portal vein ligation using multi-modal PET/MRI measurements in healthy rat liver. PLoS One 2014; 9(3): e90760.

${ }^{16}$ Budai A, Fulop A, Hahn O et al.: Animal Models for Associating Liver Partition and Portal Vein Ligation for Staged Hepatectomy (ALPPS): Achievements and Future Perspectives. Eur Surg Res. 2017; 58(3-4): 140-157.

17 Szijártó A, Hahn O, Lotz G, Schaff Z, Madarász E, Kupcsulik $P$ : Effect of ischemic preconditioning on rat liver microcirculation monitored with laser doppler flowmetry. J Surg Res 2006; 131(1): 150-157.

${ }^{18}$ Hahn O, Blázovics A, Váli L, Kupcsulik PK: The effect of ischemic preconditioning on redox status during liver resections-randomized controlled trial. J Surg Oncol. 2011; 104(6): 647-653.

${ }^{19}$ Zalaba Z, Tihanyi TF, Winternitz T, Nehéz L, Flautner L: The laparoscopic treatment of non-parasitic liver cysts. Five years experience. Acta Chir Hung. 1999; 38(2): 221-223. 
${ }^{20}$ Kupcsulik P, Ónody P: Nagyméretü hepatocelluláris karcinóma laparoszkópos reszekciója és a barcelonai kritériumok [Laparoscopic resection of giant hepatocellular carcinoma and the Barcelona staging]. Magy Onkol. 2017; 61(4): 339-342.
${ }^{21}$ Kupcsulik P, Hahn O, Szijártó A, Zsirka A, Winternitz T, Lukovich P, Fekete $K$ : [Laparoscopic surgery of benign liver tumours]. Magy Seb. 2015 Feb; 68(1): 3-7.

A cikk a Creative Commons Attribution 4.0 International License (https://creativecommons.org/licenses/by/4.0/) feltételei szerint publikált Open Access közlemény, melynek szellemében a cikk bármilyen médiumban szabadon felhasználható, megosztható és újraközölhetö, feltéve, hogy az eredeti szerző és a közlés helye, illetve a CC License linkje és az esetlegesen végrehajtott módosítások feltüntetésre kerülnek. (SID_1) 